\title{
THE MARITIME PERFORMING PARTY IN THE ROTTERDAM RULES 2009
}

Prof. Dr. Frank Smeele

Erasmus University Rotterdam

\section{INTRODUCTION}

1. In an attempt to deal uniformly with several complex and delicate legal issues that have divided the seafaring nations of the world for most of the last century, the Rotterdam Rules 2009 (hereafter: RR) introduce the concept of the "maritime performing party". ${ }^{1}$ This is a person other than the carrier who performs or undertakes to perform any of the carrier's obligations during the period between the arrival of the goods at the port of loading of a ship and their departure from the port of discharge of a ship. ${ }^{2}$ Pursuant to articles 19 and 20 RR, the maritime performing party may be held liable jointly and severally with the contractual carrier for cargo loss or damage or delay in delivery which occurred (basically) because of his own doing or during the time that the cargo was in his care.

\section{ORIGINS}

2. The Hague Rules 1924 can be seen as a successful attempt to reclaim some of the legal uniformity lost during the $19^{\text {th }}$ Century and the early $20^{\text {th }}$ Century in the field of carriage of goods by sea. Previously, even in the absence of national codifications and international conventions, there had existed a measure of international uniformity based upon mercantile custom ${ }^{3}$ as applied by commercial and admiralty courts in commercial and maritime centres around the world. ${ }^{4}$ At the time it was generally accepted that merchants and ship-owners were subject to their own laws and customs - known as the Law Merchant, the Lex Mercatoria ${ }^{5}$ and Lex Maritima ${ }^{6}$ and collected in various compilations ${ }^{7}-$ which were considered to be quite distinct from (domestic) private law in general.

3. This status aparte of merchants and ship-owners changed when separate national legal systems started to develop under the influence of the rise of the nation state and maritime law increasingly be-

\footnotetext{
See articles 1-6 and 1-7 RR and articles 19 and 20 RR.

Based on the definitions of the "performing party" in art. 1-6 RR and of the "maritime performing party" in art. 1-7 RR. These definitions will be analyzed and discussed in greater detail below in chapter 4 .

Roles d' Oléron, Coutumes de la Mer

See for a more extensive description of this historical development and further source references: R. Goode, H. Kronke, E. McKendrick, Transnational Commercial Law, Oxford, 2007, p. 12 ff. No. 1.15 ff.

See Goode, Kronke, McKendrick, Transnational Commercial Law, 2007, p. 16 ff., No. 1.20 ff.

See: W. Tetley, 'The General Maritime Law - The Lex Maritima' (1994) 20 Syracuse J. Int. L. \& Comm. 105-145 and reprinted in European Transport Law, 1996, p. 469-506.

To name a few: the Amalfitan Tables $\left(11^{\text {th }}\right.$ Century), the Rôles $d^{\prime}$ Oléron $\left(12^{\text {th }} \mathrm{C}\right)$, The Laws of Visby $\left(16^{\text {th }} \mathrm{C}\right)$, the Consolato del Mare $\left(15^{\text {th }} \mathrm{C}\right)$. A large collection of sources in this field has been collected in: Sir Travers Twiss (ed.), The black book of the Admiralty, (Four volumes), (1871), reprinted by Lawbook Exchange in the United States in 1998.
} 
came an expression of particular national legal systems. ${ }^{8}$ In civil law jurisdictions this led to efforts to codify private and commercial law at the national level. Starting with the French Ordinance de la Marine $e^{9}$ of 1681, the Prussian Allgemeines Landrecht für die Preußischen Staates ${ }^{10}$ of 1794 and the French Code de Commerce of 1807, over time virtually all continental states in Europe adopted codifications of their own. Although piecemeal legislative efforts were also undertaken in common law jurisdictions ${ }^{11}$, there the emphasis lay on the judiciary who over time developed a system of precedents based on authoritative decisions.

4. Either way, the various national legal systems which resulted, reacted differently to the challenge posed by the increasing use of far-reaching exclusion and limitation clauses in bills of lading from the 1860s onwards. In England legislative interference with the freedom of contract was deemed unnecessary and the matter was left to the discipline of the (shipping) market. In the United States however mandatory legislation was passed - the Harter Act $1893^{12}$ - regulating the liability of the ship-owner for cargo damage under bills of lading. Soon other states followed, including dominions of the British Empire such as Australia ${ }^{13}$, New Zealand ${ }^{14}$ and Canada ${ }^{15}$. It was partly in order to combat the resulting divergence of laws that in 1924 the United Kingdom was prepared to accept the mandatory Hague Rules as a mandatory and uniform liability regime for the carrier's liability for cargo damage under bills of lading.

\section{NEW PROBLEMS}

5. However it soon became clear that to impose a mandatory liability regime upon the carrier would not solve all problems. A provision such as art. III-8 Hague Rules prevents the carrier from decreasing his liability for cargo damage through bill of lading clauses, but is not so effective if the mandatory liability regime is undermined in other, more subtle, ways.

\subsection{UNCERTAINTY ABOUT THE IDENTITY OF THE CARRIER}

6. What if e.g. uncertainty arises about the identity of the carrier or difficulties occur in obtaining security for cargo claims through ship's arrest because it can no longer be taken for granted that the shipowner is necessarily the carrier under the bill of lading ? $^{16}$ In cases where other parties then the ship-ow-

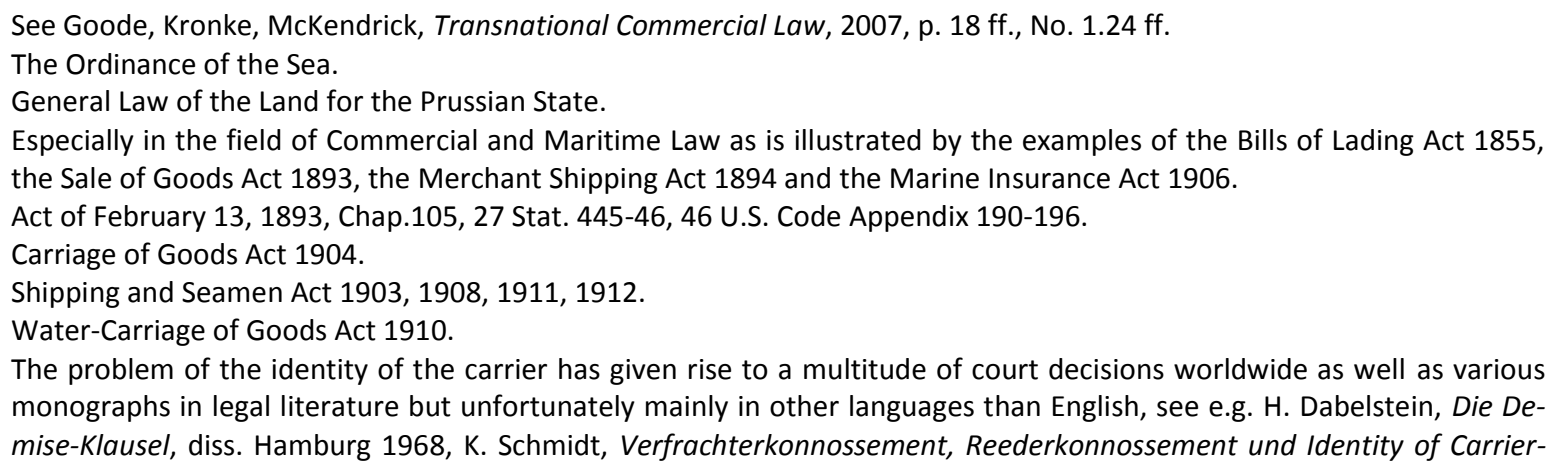
monographs in legal literature but unfortunately mainly in other languages than English, see e.g. H. Dabelstein, Die Demise-Klausel, diss. Hamburg 1968, K. Schmidt, Verfrachterkonnossement, Reederkonnossement und Identity of Carrier- 
ner, such as a time charterer or a Non Vessel Operating Carrier (NVOC) assume the role of contractual carrier under the initial contract of carriage with the shipper and/or where the bill of lading contains contradictory information about the carrier's identity ${ }^{17}$, especially a third-party holder of the bill of lading may encounter serious problems in the enforcement of his cargo claim if he has no maritime lien on the vessel, even if the claim itself is well founded and in principle covered by the carrier's P\&I insurance.

7. Unfortunately the Hague Rules do not provide answers to these problems. Therefore many legal systems have found ways of their own to protect the cargo interests ${ }^{18}$ often by treating the ship-owner as the carrier under the bill of lading or alternatively by granting the cargo claimant besides his claim against the contractual carrier an additional direct action against the actual carrier. ${ }^{19}$ Some have done so through domestic legislation ${ }^{20}$, others have left it to the Courts. ${ }^{21}$ Either way, the result was considerable legal diversity from one country to the next, which provided a strong incentive for forum shopping.

\subsection{CIRCUMVENTION OF MANDATORY LIABILITY REGIME THROUGH TORT-BASED CARGO CLAIMS}

8. A further problem arises if the cargo interests seek to escape from the exclusions and limitations of the mandatory liability regime by circumventing it. ${ }^{22}$ In principle, this can easily be done by basing the recovery claim against the contractual carrier in tort (e.g. negligence in causing damage to property) rather than on breach of the bill of lading (b/l) contract. Alternatively, the tort-based recovery claim could be brought by a claimant who is not party to the contract of carriage such as the cargo owner, or the claim could be directed (also or even exclusively) against the persons or parties ${ }^{23}$ to whom the carrier has

Klausel, Hamburg, 1980, S. Zunarelli, La nozione di vettore (contracting ed actual carrier), 1987, H. Gam, Ansvarssubjektet ved godsbeskadigelse under søtransport, diss. Copenhagen, 1991 and F.G.M. Smeele, Passieve Legitimatie uit Cognossement (The identity of the carrier under bills of lading), diss. Rotterdam, 1998. See also Zunarelli's contribution to this Conference.

E.g. where the heading and signature on the face of the bills of lading create an impression as to who is the carrier under the bill of lading, and this appearance is then contradicted by a (e.g. a Demise or identity of the Carrier) clause on the reverse side of the bill of lading. See The Starsin [2000] 1 Lloyd's Rep. 85 (CA) and [2001] 1 Lloyd's Rep. 437 (HL). For a comparative overview of Dutch, English, German, French and Belgian approaches to this problem, see: Smeele, op. cit., diss., 1998.

This is also the approach in art. 10-2 Hamburg Rules, which provides a direct action against the "actual carrier".

For Germany, see $\S 642$ HGB and for The Netherlands (previously through) art. 518d and 518k Dutch Commercial Code (old) and since 1991 through art. 8:461 and 8:462 Dutch Civil Code. See: Smeele, diss., 1998, p. 57 ff, p. 102 ff. and p. 213 ff. The Scandinavian countries have incorporated the direct action against the actual carrier already in their domestic legislation, see e.g. $\S 285$ and $\S 286$ Norwegian Maritime Code of 24 June 1994. Similar provisions can be found in the Maritime Codes of Sweden and Denmark. See: T. Falkanger, H.J. Bull, L. Brautaset, Scandinavian Maritime Law, The Norwegian perspective, $2^{\text {nd }}$ ed. Universitetsforlaget, 2004, p. $26 \mathrm{ff} .$, p. $338 \mathrm{ff}$. In Belgium e.g. the Courts have developed a doctrine under which the cargo interests may enforce a cargo claim not only against the contractual carrier, but also against the ship-owner directly. See: Cour de Cassation 30.9.1977, JPA 1977-78, 429, ETL 1980, 199 The Stad Gent and Cour de Cassation 16.9.1983 JPA 1983-84, 135 The Gold Coin. See: F. Stevens, Vervoer onder Cognossement, 2001, p. 207 ff., No. 354 ff. and Smeele, diss., 1998, p. 243 ff., p. 249 ff. For an early example of this, see: Elder Dempster v. Paterson, Zochonis, (1922) 12 LI. L. Rep. 69 (KBD); (1922) 13 LI. L. Rep. 513 (CA); [1924] AC 522, (1924) 18 LI. L. Rep. 319 (HL). often used is "Erfüllungsgehilfe" (Fulfillment assistents), in Dutch law "hulppersoon" (assisting person), in Belgian law it is "uitvoeringsagent" (performing agent) and in French law "auxiliaries" (assistents). 
delegated the performance of some or all of his obligations under the contract of carriage, i.e. his servants or agents or an independent contractor such as a sub-carrier or stevedores. ${ }^{24}$

9. Although tort-based claims generally imply a heavier burden of proof for the claimant than contractual claims under the bill of lading ${ }^{25}$, this drawback would be more than made good if the defendant was unable to raise the usual defences open to the carrier, such as exclusions and limitations of liability under the mandatory liability regime or the contract of carriage. Furthermore, if tort-based claims are possible besides the contractual claim for recovery of cargo damage, then this implies that even if the limit of liability is applied to both these claims, the claimant may recover the limitation amount more than once, i.e. from each of the liable persons.

\subsection{RESPONSES UNDER NATIONAL LAWS}

10. Obviously, this raised the question whether the mandatory liability regime applied and/or how it could be made to apply to such tort-based recovery claims against the carrier, his servants and agents and independent contractors as well. Again the Hague Rules 1924 provided no answer, so that this question was initially governed by the applicable national law, which led to much legal diversity both at the national and international level. Over time an international consensus grew that as a matter of policy such tort-based recovery claims should not be encouraged ${ }^{26}$, if not positively discouraged or even excluded. However there was no unity of approach as to who deserved protection against tort-based claims and what form that protection should take.

11. The result was a tendency among legislators and courts around the world to differentiate on a piecemeal basis between the persons and parties to whom the carrier delegates (some or all of) his obligations under the contract of carriage. ${ }^{27}$ Firstly, a distinction was drawn between the carrier, his servants

See also: M. Sturley, 'The treatment of Performing parties', CMI Yearbook 2003, p. 232: "In modern commercial shipping practice, however, the "carrier' never performs all of its duties under the contract of carriage itself. Quite apart from the fact that most carriers are corporations, which can act only through their agents, virtually every carrier today subcontracts with separate companies to perform specialized aspects of the carriage. For decades, shipowners have contracted with independent stevedores to load and unload their vessels, and with independent terminal operators to store cargo prior to loading or after discharge. With the explosion of door-to-door shipments, few (if any) carriers would even have the physical capacity to perform all their duties under a typical contract of carriage. Indeed some carriers perform none of their duties under the contract of carriage themselves. Non-vessel-operating carriers, or NVOCs, contract with the shipper to carry the cargo, but often sub-contract every aspect of the actual transportation." (footnotes omitted). If the claimant holds the defendant liable in tort, he must prove fault on the part of the defendant and a sufficient causal connection between the fault and the loss sustained. Under the Hague-Visby Rules, Hamburg Rules and Rotterdam Rules, it initially suffices for the claimant to prove that the loss occurred during the mandatory liability period of the carrier, after which it is up to the carrier to exculpate himself.

This is already visible in the inclusion of art. 6-2 into the Brussels Limitation Convention 1957. See also the extensive deliberations of the drafters of the Visby Protocols of 1968, in: F. Berlingieri (ed.), The Travaux Préparatoires of the Hague Rules and the Hague-Visby Rules, CMI, Antwerp, 1997, p. 596 ff, and: K. Grönfors, 'Non-contractual claims', in: S. Mankabady (ed.), The Hamburg Rules on the carriage of goods by sea, A.W. Sijthoff, Leyden/Boston, 1978, p. $187 \mathrm{ff}$.

An exception in this respect seem to be the Scandinavian countries Sweden, Norway and Denmark, who - with the incorporation of the Visby Rules in 1973 - have adopted an express provision in their domestic legislation to the effect that 'All persons for whom the carrier is vicariously liable can invoke the same defences and limitations of liability as 
and agents on the one hand and independent contractors on the other. This is illustrated by the Visby Protocols in 1968 which brought the first group under the protection of the mandatory liability regime, whereas the second group was left to its own devices. ${ }^{28}$

12. Secondly, many legal systems have differentiated further within the group of independent contractors of the carrier and have created separate categories and protective rules for sub-carriers, stevedores, pilots and other independent contractors. Based on sources available to this author the following categories can be distinguished on a scale ranging from full protection against tort-based claims from cargo interests to no such protection at all.

13. Some legal systems allow servants and independent contractors of the carrier immunity from liability towards third-parties, including cargo interests, except in case of their wilful misconduct. Under Belgian $^{29}$ law servants and 'performance agents' of the carrier (e.g. stevedores) benefit from such immunity from liability. Under French law stevedores ${ }^{30}$ and pilots ${ }^{31}$ are shielded from liability. Also under Dutch law pilots have immunity from liability. ${ }^{32}$ Other legal systems allow some independent contractors statutory limitation of liability. This is e.g. how the pilot is protected under English ${ }^{33}$ and Canadian Law. ${ }^{34}$

those available to the carrier.' (see e.g. § 282 (13:32) of the Norwegian Maritime Code). This includes inter alia the stevedores irrespective of whether they were engaged by the carrier or the cargo interests. See: Falkanger, Bull, Brautaset, Scandinavian Maritime Law, 2004, p. 332.

See art. IV-bis Hague-Visby Rules (HVR). Compare also art. 7 and art. 10-2 Hamburg Rules.

See: Cour de Cassation 7.12.1973, Arr. Cass. 1974, 395; Pas. 1974, I, 376, JPA 1973, 427, ETL 1974, 243, Müller-Thomsen, where it was held (in free translation) 'When the non-performance of a contract results from a fault of an employee or a performance agent of one of the parties to the contract, then the other party has an action only against his counterparty, which is a contractual action. And the employee or the performance agent cannot be considered a third-party to that contract who may be held liable in tort. At the level of the performance of the contract, the injured party only knows his counterparty, whose employee or performance agent was only an instrument. There can only be a tort-based liability if the fault of the employee or performance agent has no connection with the performance of the obligations arising out of the contract and if the damage is not purely contractual.' See more extensively, F. Stevens, Vervoer onder cognossement, 2001, p. 274, No. 456, and I. de Weerdt, 'Samenloop en coëxistentie in het maritiem recht', in: I. de Weerdt (ed.), Grondbeginselen van het Belgisch privaatrechtelijk Zeerecht, Vol. I, Antwerp, 1998, p. 275 ff, No. 349-353.

This follows from art. 52 of the Act No. 66-420 of 18 June 1966 which provides that: "l'entrepreneur de manutention opère pour le compte de celui qui aura requis ses services, et sa responsabilité n'est engagée qu'envers celui-ci qui seul a une action contre lui. " (the stevedore acts for the account of he who requested his services and may not be held liable except by his principal, who alone has a right of action against the stevedore.). Cf. Cour de Cassation 5.7.1994, Droit Maritime Français (DMF) 1994, 648 [The Casablanca]. However in: Cour de Cassation 4.7.2000, DMF 2001, p. 24 ff. [Lorientaise d'armement $v$. SGMT] an exception was made on the immunity from liability of the stevedore in case the third-party possessed no recovery action at all against the party who instructed the stevedores. See more extensively: P. Bonassies, C. Scapel, Droit Maritime, LGDJ, Paris, 2006, p. 442 ff, No. 680ff.

Under art. 18 of the Act of 3 January 1969. See: Bonassies/Scapel, Traité de Droit Maritime, 2006, p. 466, No. 716.

See art. 3 Loodsenwet (Pilots Act) which reads as follows in translation: "To the extent that he acts in the performance of the duties and powers listed in article 2, the pilot is only liable for damage caused with intent or gross negligence." In The Solon (Hoge Raad (HR) 4.2.2000, Schip \& Schade (S\&S) 2000, 62), it was clarified that "grove schuld" (gross negligence) in art. 3 Loodsenwet means an act or omission of the pilot which occurred recklessly and with knowledge that damage would probably result. In two decisions given in a CMR context, - HR 5.1.2001, S\&S 2001, 62, ETL 2001, p. $97 \mathrm{ff}$. [Van der Graaf/Philip Morris] and HR 5.1.2001, S\&S 2001, 61, ETL 2001, p. 116 [Cigna/Overbeek] - the Dutch Supreme Court has developed its interpretation of these words further: 'if the acting person knows the risk inherent in his act and is aware that the chance that this risk will manifest itself, is considerably greater than the chance that this will not hap- 
14. The most common type of protection against tort-based claims from the cargo interests is to allow the servants and agents of the carrier to invoke the defences, exclusions and limitations available to the carrier under the mandatory liability regime. ${ }^{35}$ Some legal systems apply this rule also to all independent contractors to whom the carrier delegates (some of) his obligations under the contract of carriage. As mentioned above ${ }^{36}$ the Scandinavian countries have adopted a rule to the effect that all persons for whom the carrier is vicariously liable, can invoke the same defences, exclusions and limitations of liability as those available to the carrier. ${ }^{37}$ Under German law the group of persons entitled to invoke the defences, exclusions and limitations of liability of the carrier includes the servants of the carrier ${ }^{38}$, the crew of the ship $^{39}$ and the ship-owner ${ }^{40}$, but does not extend to other independent contractors such as stevedores or sub-carriers. ${ }^{41}$

15. Under Dutch law sub-carriers and servants of the carrier and sub-carriers can invoke the defences, exclusions and limitations of liability open to the carrier not only under the mandatory liability regime, but also under the contract of carriage. ${ }^{42}$ However this rule does not extend to other independent con-

pen, yet all this does not restrain him from that act.' See about these decisions, Smeele, 'Dutch case law on art. 29 CMR revisited', ETL 2001, p. $37 \mathrm{ff}$. Under section 22 (1) Pilotage Act 1987, the liability of pilots is limited to an amount of $f 1,000$ increased with the amount of the pilot charges of the voyage during which the liability arose.

Under Section 40 Pilotage Act 1985, the liability of pilots is limited to 1,000 Canadian dollars. See: E. Gold, A. Chircop, H. Kindred, Maritime Law, Irwin Law, 2003, p. 570.

See art. IV-bis HVR and art. 7 and 10-2 Hamburg Rules.

See footnote 27. P.M.

$\S 282$ (13:32) of the Norwegian Maritime Code. Interestingly, art. 1-4 LLMC uses a similar criterion to define the group of persons who may avail themselves of the right to limitation of liability for maritime claims under the 1976 London Limitation Convention. Art. 1-4 LLMC reads as follows: "If any claims set out in Article 2 are made against any person for whose act, neglect or default the ship-owner or salvor is responsible, such person shall be entitled to avail himself of the limitation of liability provided for in this Convention."

See $\S 607 a$ II HGB (Handelsgesetzbuch or German Commercial Code): „Wird ein Anspruch auf Ersatz des Schadens wegen Verlusts oder Beschädigung von Gütern, die Gegenstand eines Frachtvertrages sind, gegen einen der Leute des Verfrachters oder eine Person der Schiffsbesatzung geltend gemacht, so kann diese Person sich auf die Haftungsbefreiungen und Haftungsbeschränkungen berufen, die in diesem Abschnitt für den Verfrachter vorgesehen sind." (If a claim for compensation of damage is made against one of the employees of the carrier or a member of the crew of the ship in relation to loss of or damage to goods, which are the object of a contract of carriage, then that person can invoke the exclusions and limitations of liability which are provided for in this chapter.)

$\S 607 a$ II HGB.

See $\S 485$ HGB: „Der Reeder ist für den Schaden verantwortlich, den eine Person der Schiffsbesatzung oder ein an Bord tätiger Lotse einem Dritten in Ausführung von Dienstverrichtungen schuldhaft zufügt. Er haftet den Ladungsbeteiligten jedoch nur soweit, wie der Verfrachter ein Verschulden der Schiffsbesatzung zu vertreten hat." (The shipowner is liable for the damage which a member of the crew or a pilot active on board causes to a third party through his fault in the performance of services. However, towards the cargo interests he is only liable to the extent that the carrier is liable for a fault of the ship's crew.)

See: D. Rabe, Seehandelsrecht, $4^{\text {th }}$ Ed., Beck, Munich, 2000, $§ 607 a$, RdNr. 7 a); R. Herber, Seehandelsrecht, De Gruyter, Berlin, New York, 1999, p. $335 \mathrm{ff}$.

Dutch law has a comprehensive but rather complex statutory system of so-called "derdenwerking" (third-party effect) of contracts of affreightment and contracts of carriage in articles 8:361 to 8:366 Dutch Civil Code (DCC). It aims to discourage the claimant in tort by confronting him where possible with the defences, exclusions and limitations of liability in the contract of carriage to which he is a party and under the applicable liability regime. The basic approach is illustrated by art. 8:365 DCC which provide for the benefit of the servant of the carrier or sub-carrier as follows: 'Where an action (...) is instituted extra-contractually against a servant of a party to a contract of operation, and where that party, in order to rebut its liability for the conduct of the servant, can derive a defence against the plaintiff from the contract governing 
tractors such as stevedores or a ship repair yard. Under the common law doctrine of "bailment on terms", the ship-owner as sub-bailee of the goods may invoke defences under his own sub-contract with the contractual carrier when confronted with a tort-based liability claim from the cargo interests. ${ }^{43}$ From 1955 until 1991 Dutch law had a statutory provision in art. 321-3 Dutch Commercial Code which produced a similar result. ${ }^{44}$

\subsection{Himalaya Clauses}

16. Thirdly, if under the applicable law a servant, agent or independent contractor of the carrier is not shielded by any of the above forms of protection, and if he is neither a party to or beneficiary of the contract of carriage, then under the principle of privity of contract he cannot benefit from any defences, exclusions and limitations of liability available to the carrier under that contract of carriage. ${ }^{45}$ This explains the widespread phenomenon of including so-called Himalaya clauses ${ }^{46}$ in bills of lading. A typical example of a modern Himalaya clause ${ }^{47}$ is clause 15 of the Conlinebill 2000 which reads as follows:

“15. Defences and Limits of Liability for the Carrier, Servants and Agents

(a) It is hereby expressly agreed that no servant or agent of the Carrier (which for the purpose of this Clause includes every independent contractor from time to time employed) shall in any circumstances whatsoever be under any liability whatsoever to the Merchant under this Contract of carriage for any loss, damage or delay of whatsoever kind arising or resulting directly or indirectly from any act, neglect of default on his part while acting in the course of or in connection with his employment.

(b) Without prejudice to the generality of the foregoing provisions in this Clause, every exemption from liability, limitation condition and liberty herein contained and every right, defence and immunity of whatsoever nature applicable to the Carrier or to which the carrier is entitled, shall also be available and shall extend to protect every such servant and agent of the Carrier acting as aforesaid.

its liability (...), the servant may also invoke this defence, as if he were a party to the contract himself.' Articles 8:363 and 8:364 DCC provide rules to the same effect for the benefit of the ship-owner or charterers as a sub-carrier. In art. 8:3611 DCC the term 'exploitatie-overeenkomsten' (contracts of operation) is defined as: 'the contracts of affreightment and the contracts of carriage of goods or persons by the vessel.'

See: The Pioneer Container [1994] 2 AC 324, [1994] 1 Lloyd's Rep. 593 (PC) and N. Gaskell, R. Asariotis, Y. Baatz, Bills of Lading: Law and Contracts, LLP, 2000, p. 398 ff., Nos. 12.46-12.51; and S. Girvin, Carriage of Goods by Sea, Oxford, 2007, p. 106 ff., Nos. 9.18-9.22, with further case and literature references.

Art. 321-3 of the Dutch Commercial Code (old) provided that in relation to damage caused to persons or goods carried on board of the ship, the "reeder" (operator) of the ship was entitled to invoke the contract of carriage or contract of affreightment as concluded by him with his counterparty. At the time, art. 320 Dutch Commercial Code (old) defined "reeder" as he who uses the ship for navigating the sea and who either commands it himself or lets it be commanded by a master who is in his service. Practically speaking therefore the registered ship-owner or the bareboat charterer.

Under English law see: Adler v. Dickson, [1955] Q.B. 158, [1954] 2 Lloyd's Rep. 267 (CA) and Scruttons v. Midland Silicones, [1962] A.C. 446, [1961] 2 Lloyd's Rep. 365 (HL). The US Supreme Court reached the same conclusion in Herd \& Co. v. Krawill Machinery Corp., 359 U.S. 297 (1959). See for further references: Schoenbaum, Admiralty and Maritime Law, $4^{\text {th }}$ Ed., Thomson West, 2001, § 8-8, p. 538 ff. See also the Australian case of Wilson v. Darling Island Stevedoring Co. [1956] 1 Lloyd's Rep. 346.

Named after the vessel in Adler v. Dickson, [1955] Q.B. 158, [1954] 2 Lloyd's Rep. 267 (CA). The case concerned a personal injury claim by Mrs. Adler against the master and Boatswain of the cruise vessel "Himalaya". When boarding the vessel at Trieste, the badly secured gangway came loose and Mrs. Adler fell a distance of 16 feet and suffered severe injuries including a broken leg, a broken pelvis and broken ribs. The Court of Appeal held that the defendants could not rely on the exemption clause in the passage ticket received by Mrs. Adler as they were not party to this contract.

Various other formulations of this clause are used in maritime and commercial practice as well, for an overview see: Gaskell, Asariotis, Baatz, Bills of lading: Law and Contracts, 2000, p. 383 ff., Nos. 12.20-12.27. 
(c) The Merchant undertakes that no claim shall be made against any servant or agent of the Carrier and, if any claim should nevertheless be made, to indemnify the Carrier against all consequences thereof.

(d) For the purpose of all the foregoing provisions of this Clause the carrier is or shall be deemed to be acting as agent or trustee on behalf of and for the benefit of all persons who might be his servants or agents from time to time and all such persons shall to this extent be or be deemed to be parties to this Contract of Carriage."

17. As follows from part (d) of this clause, one of the main objectives of a Himalaya clause is to create a contractual relation between the cargo interests and the servant, agent or independent contractor of the carrier on the terms of the contract of carriage. Secondly, as follows from parts (a) and (c), this Himalaya clause tries to achieve by contractual means an immunity from liability for 'all servants and agents of the carrier (including every independent contractor from time to time employed)'. Only if that does not work part (b) aims to bring the beneficiaries of this clause in the same position as the Carrier so that every exemption or limitation of liability under the terms of the contract of carriage (hereafter for the sake of brevity and easy reference jointly to be referred to as: contractual defences), as well as every liberty, right, defence or immunity available to the carrier under the applicable liability regime (hereafter: statutory defences) is also available to them. Provided that the wording of the clause is adequate to protect the persons seeking to benefit from it ${ }^{48}$, courts around the world ${ }^{49}$ have generally upheld Himalaya clauses $^{50}$, although the way the clause is construed in common law and civil law jurisdictions differs. ${ }^{51}$

\section{$4 \quad$ UNIFORM SOLUTIONS}

This was more difficult under English law than in other legal systems because of the privity of contract-doctrine and the requirement of consideration. In: Midland Silicons v. Scruttons [1961] 2 Lloyd's Rep. 365 (HL), the clause relied upon was still inadequate to bring the stevedores in a contractual relationship with the shipper. However, in The Eurymedon [1974] 1 Lloyd's Rep. 534 (PC), the majority of the Privy Council gave effect to the Himalaya clause, which decision was endorsed by the Privy Council again in The New York Star [1980] 2 Lloyd's Rep. 317 (PC). In The Makhutai [1996] AC 650, [1996] 2 Lloyd's Rep. 1 (PC), the Privy Council held that the ship-owners could not invoke a jurisdiction clause in the bill of lading for the Courts of Indonesia as this jurisdiction clause was not an exception, limitation, condition or liberty as meant in the Himalaya clause in that case. For The Netherlands, see: HR 5.9.1997, S\&S 1997, 121 The Sriwijaya. For Germany, see: Bundesgerichtshof (BGH or Federal Supreme Court) 7.7.1960, Versicherungsrecht (VersR) 1960, p. 727 ff., Oberlandesgericht (OLG or Court of Appeal) Hamburg 7.11.1974, VersR 1975, p. 801 ff., BGH 28.4.1977, VersR 1977, p. 717 ff., BGH 26.11.1979, VersR 1980, p. 572 ff., K. Schmidt, 'The Himalaya Clause under the Law of the Federal Republic of Germany', ETL 1984, p. 675 ff., Rabe, Seehandelsrecht, 2000, § 607a HGB, RdNr. 10-13. For Belgium, see: F. Stevens, Vervoer onder cognossement, 2001, p. 273 ff., Nos. 455 ff., with further literature and case references. For England, see: G.H. Treitel, F.M.B. Reynolds, Carver on Bills of Lading, Sweet \& Maxwell, $2^{\text {nd }}$ Ed. 2005, Nos. 7-047 ff., Girvin, Carriage of Goods, 2006, p. 112, No. 9.27 who also gives further case references for Australia, Canada and South Africa. For the USA see the decision of the U.S. Supreme Court in: Norfolk Southern Railway Co. v. James N. Kirby Pty Ltd, 543 U.S. 14 (2004) and Schoenbaum, Admiralty and Maritime Law, 2001, § 8-8, p. $540 \mathrm{ff}$. with further case references. A typical Himalaya clause is Clause 15 of the BIMCO Liner Bill of Lading (Conlinebill 2000) riage and stipulates defences, exclusions and limitations of liability he does so also as an agent for his servants, agents and independent contractors. Civil law jurisdictions on the other hand understand the Himalaya clause as a stipulation for the benefit of a third party. When concluding the contract of carriage, the carrier stipulates defences, exclusions and limitations of liability for the benefit of his servants, agents and independent contractors. 
18. In view of the considerable international divergence in responses to the reality of tort-based cargo damage claims against the carrier, his servants, agents and independent contractors as well as the uncertainty about the identity of the carrier under bills of lading, it is no surprise that at the international level soon efforts were made to provide uniform solutions to these problems.

\subsection{Application to nON-CONTRActual Claims}

19. The first uniform rule to materialize from this international legislative process is that the mandatory liable regime will apply to all claims for compensation of damage to cargo irrespective of their legal basis, whether contractual or non-contractual. This rule was introduced at the international level with the 1955 Hague Protocols to the Warsaw Convention on carriage by air. ${ }^{52}$ Since then it has become one of the general rules of transport law, included in all modern transport law conventions. ${ }^{53}$ However, this rule does not apply ${ }^{54}$ if it is proved that the damage resulted from an act or omission of the person held liable done with intent to cause damage or recklessly and with knowledge that damage would probably result. $^{55}$

20. The above rule was included in the Hague-Visby Rules $1968^{56}$ and in a slightly extended formulation also in the Hamburg Rules. ${ }^{57}$ In the Rotterdam Rules 2009 this rule can be found in art. 4-1 RR:

Article 4 RR Applicability of defences and limits of liability

1. Any provision of this Convention that may provide a defence for, or limit the liability of, the carrier applies in any judicial or arbitral proceeding, whether founded in contract, in tort, or otherwise, that is instituted in respect of loss of, damage to, or delay in delivery of goods covered by a contract of carriage or for the breach of any other obligation under this Convention against:

(a) The carrier or a maritime performing party;

(b) The master, crew or any other person that performs services on board the ship; or

(c) Employees of the carrier or a maritime performing party. (with added stress - FS).

21. Art. 4-1 RR focuses solely on the application of the statutory defences under the mandatory liability regime and does not make clear whether the carrier or a maritime performing party or the persons listed under (b) and (c) may also invoke any additional defences under the contract of carriage (if any) in response to tort-based cargo claims. This is relevant because, whereas Himalaya clauses routinely provide that both contractual and statutory defences may be invoked, the Hague-Visby Rules, Hamburg Ru-

See: art. 24-1 of the Warsaw Convention as amended by the Hague Protocol of 28 September 1955: "In the cases covered by Articles 18 and 19 any action for damages, however founded, can only be brought subject to the provisions of this Convention. Similar provisions from the same era are art. 28-1 CMR 1956 and art. 40-1 Cotif-CIM 1961.

See: art. 7-1 Hamburg Rules, art. 20-1 UN Convention on International Multimodal Transport of Goods (MTG) 1980, art. 22 CMNI, art. 29 Montreal Convention (MC) 1999, art. 41 Cotif-CIM 1999.

The unbreakable limits in case of carriage of goods by air under art. 22-5 MC is the one notable exception.

See art. 29 CMR, art. IX Guadalajara Convention, art. IV-5 (e), art. IV-bis (4) HVR, art. 8 Hamburg Rules, art. 21 MTG, art. 36 Cotif-CIM, art. $21 \mathrm{CMNI}$ and art. 61 RR. For no apparent reason, under art. 61 RR only the right to limit is lost, whereas the other conventions also mention expressly loss of the right to invoke exclusions from liability.

Article IV-bis (1) HVR.

Art. 7-1 Hamburg Rules. 
les and Rotterdam Rules provide so only for the statutory defences and leave the question of the admissibility of additional contractual defences undecided.

22. Both the Hamburg Rules and the Rotterdam Rules do provide that a maritime performing party is not bound by any additional obligations voluntarily undertaken or higher limits of liability accepted ${ }^{58}$ by the contractual carrier in excess of his statutory liability regime under these conventions, unless he has expressly agreed to it. ${ }^{59}$ Furthermore it is clear that to the extent that a clause in the contract of carriage actually departs from the liability regime of the Rotterdam Rules in favour of the performing party ${ }^{60}$, or to the detriment of the cargo interests ${ }^{61}$, it would be null and void. ${ }^{62}$

23. However this does not imply that the uniform liability regime of the Rotterdam Rules must be deemed so comprehensive and mandatory that it precludes any additional arrangements of whatever nature in the contract of carriage between the shipper and the carrier. In fact, as a thought-experiment, such comprehensiveness of the Rotterdam Rules regime might prove quite undesirable, as it implies that the shipping industry would lose the essential ability to respond adequately and proportionally through its contractual terms to any new problems which may emerge in maritime and commercial practice e.g. as a result of technological innovation or business reorganisation.

24. It follows that there may very well remain a grey area of aspects and clauses under the contract of carriage which the Rotterdam Rules have not already provided for and which therefore is neither unnecessary nor null and void. In that case, it seems that although the Rotterdam are silent on this, the carrier can invoke such 'grey area' provisions against the shipper based upon their contractual relation and against the consignee to the extent that the latter is bound under the applicable law to the terms of the contract of carriage. ${ }^{63}$ With regard to maritime performing parties and persons listed in art. 4-1 under (b) and (c) RR, the Rotterdam Rules provide no basis either to invoke 'grey area' terms in the contract of carriage. Consequently, for these parties it may remain necessary to persuade carriers to retain a properly modified Himalaya clause in the contract of carriage once the Rotterdam Rules enter into force.

Although the Hague-Visby Rules, the Hamburg Rules and the Rotterdam Rules are of a mandatory nature, it is permitted under art. III-8 HVR, art. 22-1 Hamburg Rules and art. 79-1 (a) RR for the (contractual) carrier to increase his obligations under the contract of carriage.

See art. 19-2 RR: "Liability of maritime performing parties (...) 2. If the carrier agrees to assume obligations other than those imposed on the carrier under this Convention, or agrees that the limits of its liability are higher than the limits specified under this Convention, a maritime performing party is not bound by this agreement unless it expressly agrees to accept such obligations or such higher limits.". See also art. 10-3 Hamburg Rules.

E.g. through the immunity from liability stipulated for independent contractors of the carrier under part (a) of the Himalaya clause from the Conlinebill 2000. See above under No. 16 ff. P.M.

E.g. by imposing additional obligations upon them as "merchants" through clauses 9. "Loading and discharging" and 10. "freight, charges, costs, expenses, duties, taxes and fines" of the Conlinebill 2000.

See art. 79-1 and -2 RR.

For a comparative analysis of how the position of the consignee under the contract of carriage is construed under three civil law systems, German, French and Dutch law, see: Smeele, 'Bill of lading contracts under European national laws (civil law approaches to explaining the legal position of the consignee under bills of lading), Chapter 12 in: D.Rhidian Thomas (ed.), The evolving law and practice of Voyage Charter Parties, Informa, London, 2009, p. 251-280. 
25. Another reason to retain a Himalaya clause in the contract of carriage for the sake of independent contractors as well as for their servants and agents, is that the rule in art. 4-1 RR has its own scope of application under art. 19-1 RR, which differs from that of the Rotterdam Rules as a whole. ${ }^{64}$ Consequently, even under the Rotterdam Rules there may be situations where an independent contractor performing carrier's obligations in connection with the maritime part of the contract will not be able to invoke the mandatory liability regime of the Rotterdam Rules in his defence and is left unprotected against tortbased claims.

\subsection{THE AGgREGATE LIABILITY RULE}

26. It follows from the above that the transport law conventions do not block tort-based claims as such, but merely provide that statutory exclusions and limitations of liability can be invoked in defence. As mentioned already ${ }^{65}$, this does not suffice because unless the claimant is prevented from recovering the limitation amount more than once from the various liable parties, it is still possible for cargo interests to circumvent the mandatory liability regime with tort-based claims. For this reason a second uniform rule is needed that to the effect that the aggregate of what can be recovered from all beneficiaries of the mandatory liability regime, may not exceed the applicable limitation amount. Again this rule originates from the 1955 Hague Protocols ${ }^{66}$ and has subsequently become a general rule of transport law to be found in most modern transport law conventions. ${ }^{67}$

\subsection{EXPANSION OF THE GROUP OF BENEFICIARIES OF THE MANDATORY LIABILITY REGIME}

27. The third topic for which uniform rules were devised concerns the progressive expansion of the group of persons around the carrier who may benefit from the mandatory liability regime. Three separate sub-groups can be detected in this extension process so far.

\subsubsection{Employees}

28. The first sub-group concerns employees of the carrier and of the actual carrier/maritime performing party. The 1955 Hague Protocols to the Warsaw Convention ${ }^{68}$, brought the servants and agents of the carrier under the protection of the mandatory liability regime for the first time. Although this concept has evolved further since then, by now the basic idea of protecting employees of the carrier from

See below § 4.3.3, No. 39 ff. P.M.

See above under No. 9.

See art. 25A-2 Amended Warsaw Convention 1955 and art. VI Guadalajara Convention 1961.

See: art. IV-bis (3) HVR 1968, art. 7-3 and art. 10-5 Hamburg Rules 1978, art. 20-3 MTG 1980, art. 30-2 MC 1999, art. 205 CMNI 2001, art. 20-2 RR. The only exceptions are CMR 1956 and Cotif-CIM 1999 which do not contain an express aggregate rule. Arguably however such a provision is implied in a system of limited liability anyway.

68

See art. 25A Amended Warsaw Convention 1955: "If an action is brought against a servant or agent of the Carrier arising out of damage to which this Convention relates, such servant or agent, if he proves that he acted within the scope of his employment, shall be entitled to avail himself of the limits of liability which that carrier himself is entitled to invoke under Article 22." 
tort-based cargo claims in relation to acts and omissions done within the scope of their employment has become a common feature to all modern transport law conventions. ${ }^{69}$

29. The basic rationale for this rule is that if persons who are economically dependent upon the carrier are not protected by the defences available to the carrier, then the ultimate financial burden of the claim is likely to be borne by the carrier who under the social legislation of many countries is bound to compensate his employees for such third-party liability. ${ }^{70}$ That would undermine in an indirect way the basic risk allocation between the cargo interests and the carrier under the various transport law conventions.

30. In the field of carriage of goods by sea, this concept was introduced by art. IV-bis (2) HVR $1968^{71}$, which allows the servants and agents of the carrier to invoke both exclusions and limitations of liability ${ }^{72}$, yet expressly excludes any independent contractors of the carrier from the scope of protection. ${ }^{73}$ The Hamburg Rules 1978 extended the protection of the mandatory liability regime to servants and agents of both the contractual and the actual carrier ${ }^{74}$, yet expressly provided that it applied only to their acts and omissions done within the scope of their employment. ${ }^{75}$

31. Under art. 4-1 RR the defences and limitations of liability provided by the Rotterdam Rules to the carrier and a maritime performing party also apply to: “(b) the master, crew or any other person that performs services on board the ship; and (c) employees of the carrier or a maritime performing party" irrespective of whether these persons acted within the scope of their employment or not. Whereas the former criterion focuses on the (service) relationship towards the ship, under the latter it is the employment relation with the carrier or a maritime performing party which is decisive. Evidently, these criteria may overlap when the master and crew are employed by the contractual carrier or by a maritime performing party. However under modern employment arrangements seafarers are often employed by a placement agency who lends him to the ship-owner under a placement service agreement to work on board of the ship. In such cases it is definitely useful to clarify that the master, crew and all other persons working on board the ship are protected by the mandatory liability regime of the Rotterdam Rules in their

69

72

See: art. 28-2 CMR, art. V Guadalajara, art. IV-bis (2) HVR, art. 7-2 and 10-2 Hamburg Rules, art. 20-2 MTG, art. 30 and art. $43 \mathrm{MC}$, art. 41-2 Cotif-CIM, art. 17-3 CMNI, and art. 4-1 RR.

See the intervention of C. Miller in: The Travaux Préparatoires of the Hague and Hague-Visby Rules, p. 600. Cf. T. Fujita, 'The Comprehensive Coverage of the New Convention: Performing Parties and the Multimodal implications', 44 Texas International Law Journal, p. $349 \mathrm{ff}$, at p. 370 [2009].

Art. IV-bis (2) HVR reads as follows: "2. If such an action is brought against a servant or agent of the carrier (such servant or agent not being an independent contractor), such servant or agent shall be entitled to avail himself of the defences and limits of liability which the carrier is entitled to invoke under these Rules."

Art. 25A of the Amended Warsaw Convention 1955 mentioned only the limits of liability. However as from art. 28-2 CMR 1956 onwards all transport law conventions allow the servants and agents of the carrier to invoke both exclusions and limitations of liability. See: Art. 5 Guadalajara, art. IV-bis (2) HVR, art. 7-2 and 10-2 Hamburg Rules, art. 20-2 MTG, art. 30 and art. 43 MC, art. 41-2 Cotif-CIM, art. 17-3 CMNI.

This is a unique feature of the Hague-Visby Rules, no other modern transport law conventions makes this restriction.

See art. 7-2 and 10-2 Hamburg Rules. This extension was first introduced in art. V Guadalajara and appears also in art. 20-2 MTG, art. 30 and art. 43 MC and art. 17-3 CMNI.

See art. 7-2 Hamburg Rules. This restriction was introduced in art. 25A Amended Warsaw Convention and appears also in art. 28-2 j $^{\circ}$ art. 3 CMR, art. V Guadalajara, art. 20-2 MTG, art. 30 and 43 MC, art. $41 j^{\circ}$ art. 40 Cotif-CIM, art. 17-3 CMNI. 
own right, if only to avoid debate about whether or not their employer qualifies as a maritime performing party under art. 1-7 RR.

32. Arguably, the Rotterdam Rules go a step further than all previous conventions by creating a quasiliability immunity for these seafarers and the employees of the contractual carrier and maritime performing parties. Although the Travaux Préparatoires of the Rotterdam Rules do not shed much light on this, it seems to follow from art. 19-4 RR in conjunction with art. 18-1 RR and art. 4-1 RR, that - except for cases where the right to limit is lost ${ }^{76}$ - the persons listed in art. 4-1 (b) and (c) RR cannot be held liable for their acts or omissions causing loss of or damage to or delay in delivery of the cargo.

33. This proposition is supported firstly by the clear wording of art. 19-4 RR which provides that: "Nothing in this Convention imposes liability on the master or crew of the ship or on an employee of the carrier or of a maritime performing party." If we read art. 19-4 RR in combination with art. 18 RR then it follows that even if the carrier is liable for a breach of his obligations caused by an act or omission from (b) the master or crew of the ship or (c) employees of the carrier or a performing party, the Rotterdam Rules do not impose liability on the master, crew of employees under the Rotterdam Rules.

34. Secondly, it is clear that art. 19-4 RR will provide a defence for these people if they are nevertheless held liable under the Rotterdam Rules. This brings us back to art. 4-1 RR which provides that 'any provision which may provide a defence for or limit the liability of the carrier' applies also in case of a claim for loss of, damage to or delay in delivery of the goods or for the breach of any other obligation of the carrier under the Rotterdam Rules made against amongst others the persons listed under (b) and (c). Admittedly, art. 4-1 RR refers only to defences and limitations of the carrier which may be invoked and not to any defences of the persons listed under (b) and (c), however if these persons may even invoke defences of the carrier, surely they may invoke their own immunity defence under art. 19-4 RR!

\subsubsection{Actual carrier}

35. Whereas the Hague-Visby Rules $1968^{77}$ only protected servants and agents of the carrier and excluded independent contractors, the Hamburg Rules 1978 extended the group of protected beneficiaries with a concept borrowed from air law ${ }^{78}$, i.e. the "actual carrier" ${ }^{\prime 79}$, as well as his servants and agents. ${ }^{80}$

See art. 61-1 RR.

See art. art. IV-bis (2) HVR.

See Art. I (c) Guadalajara Convention: "'actual carrier' means a person, other than the contracting carrier, who by virtue of authority from the contracting carrier, performs the whole or part of the carriage contemplated in paragraph $b$ but who is not with respect to such part a successive carrier within the meaning of the Warsaw Convention. Such authority is presumed in the absence of proof to the contrary." See also art. II and V Guadalajara.

Art. 1-2 Hamburg Rules: "2. "Actual carrier" means any person to whom the performance of the carriage of the goods, or of part of the carriage, has been entrusted by the carrier, and includes any other person to whom such performance has been entrusted.". See about this concept more extensively: J. Kienzle, Die Haftung des Carrier und des Actual Carrier nach dem Hamburg-Regeln, diss. Hamburg, Luchterhand, 1993, p. 55 ff., p. 89 ff. Since the adoption of the Hamburg Rules in 1978, the concept of the "actual carrier" was included in most other recent transport law conventions, see art. $39 \mathrm{ff}$. MC, art. 4 and art.17 CMNI and art. 27 Cotif-CIM, with the exception of the unsuccessful 1980 MTG Convention. 
This concept applies to sub-carriers ${ }^{81}$, but not to parties who merely assist the carrier in the performance of the carriage of goods ${ }^{82}$ or in the performance of his other obligations under the contract of carriage. ${ }^{83}$

\subsubsection{Maritime Performing Party}

36. The drafters of the Rotterdam Rules 2009 have transformed and extended the concept of the actual carrier further to arrive at the notion of "maritime performing party", as defined in art. 1-7 RR. As this latter definition refers to that of the "performing party" in art. 1-6 RR, both definitions will be cited here for easy reference:

For the purposes of this Convention: (...)

6.(a) 'Performing party' means a person other than the carrier that performs or undertakes to perform any of the carrier's obligations under a contract of carriage with respect to the receipt, loading, handling, stowage, carriage, care, unloading or delivery of the goods, to the extent that such person acts, either directly or indirectly, at the carrier's request or under the carrier's supervision or control.

(b) 'Performing party' does not include any person that is retained, directly or indirectly, by a shipper, by a documentary shipper, by the controlling party or by the consignee instead of by the carrier.

7. "Maritime performing party" means a performing party to the extent that it performs or undertakes to perform any of the carrier's obligations during the period between the arrival of the goods at the port of loading of a ship and their departure from the port of discharge of a ship. An inland carrier is a maritime performing party only if it performs or undertakes to perform its services exclusively within a port area.

37. The notion of "performing party" plays only a subordinate role in the system of the Rotterdam Rules. ${ }^{84}$ The Rotterdam Rules assume that the carrier may delegate performance of his carriage or cargo handling obligations under the contract of carriage to a sub-contractor, the performing party. ${ }^{85}$ Such delegation of duties does not affect the carrier's liability under the contract of carriage, because he remains liable for any breach of his obligations under the Rotterdam Rules caused by an act or omission of any performing party or his employees. ${ }^{86}$ Neither do the Rotterdam Rules offer the performing party any protection against tort-based claims or impose any obligations upon him as such or make him liable for

See art. 10-2 Hamburg Rules. See also the notion of the actual carrier under

I.e independent contractors who (agree to) perform the carriage of goods or part of it for the carrier.

E.g. a pilot or a harbour tug assisting the vessel in mooring along the quay.

E.g. stevedores performing the loading, transshipment or discharging operations of the goods or a terminal operator who stores the goods prior to loading or after discharge.

The explanation for this is that the notion of performing party is so wide that it extends also to any inland sub-carriers whether by road, rail or inland barge. Therefore any provisions in the Rotterdam Rules regulating the position of a nonmaritime performing party are likely to conflict with the European unimodal transport law conventions CMR, Cotif-CIM or CMNI respectively.

Many provisions dealing with aspects of the performance of the contract of carriage, mention the performing party immediately after the carrier. See e.g. articles 12-1, 15, 16, 17-3 (i), 23-1 and -5, 29-1 (a), 32 (a), 34, 35, 36-2 and -4, 39-2 and $-3,40-3$ and $-4,44$ RR.

See art. 18 (a) and (c) RR. Cf. T. Fujita, op. cit., 44 T. Int.L.J., p. 349 ff, at p. 367 ff. [2009]. The rule in art. 18 RR could not be restricted to maritime performing parties only in view of the scope of application of the Rotterdam Rules (see art. 5 and art. $26 \mathrm{RR}$ ) which is wider than mere maritime transport and which may extend also to inland carriage prior to or subsequent to carriage by sea performed by sub-carriers by road, rail or barge as a (non-maritime) performing party. 
anything. ${ }^{87}$ In the end, the main relevance of the "performing party" is that the concept of the "maritime performing party" is based upon it. ${ }^{88}$

38. This implies that the key elements of the definition of the performing party in art. 1.6 RR apply equally to the maritime performing party as defined in art. 1.7 RR and need to be explored and examined more closely to arrive at a better understanding of what the concept of the "maritime performing party" in art. 1.7 RR entails:

- "a person other than the carrier": By definition, the carrier cannot be his own maritime performing party. The concept presupposes that an independent contractor or an agent performs certain obligations for the carrier. If and to the extent that the carrier performs any obligations under the contract of carriage himself ${ }^{89}$, there is no room for a separate maritime performing party. It must be presumed that the same applies if the obligation is performed by employees of the carrier or of the maritime performing party or by the master and crew of the ship. ${ }^{90}$ Not only do the Rotterdam Rules distinguish these employees, master and crew conceptually ${ }^{91}$ from their employers, the carrier or the maritime performing party, also their legal position is entirely different. ${ }^{92}$

- "a person ... that performs or undertakes to perform": The maritime performing party concept extends not only to a party who actually performs certain obligations of the carrier under the contract of carriage. It applies equally to an independent contractor (PP1) who merely undertakes to perform this obligation of the carrier, but in fact delegates performance to another party (PP2). It follows that there may be two or more maritime performing parties (PP1, PP2, PPx) simultaneously in relation to the fulfilment of the same obligation, if performance of that obligation is sub-contracted further by the maritime performing party. ${ }^{93}$

- "any of the carrier's obligations under a contract of carriage with respect to the receipt, loading, handling, (keep ${ }^{94}$ ), stowage, carriage, care, unloading or delivery of the goods": In order to qualify

See art. 4-1 RR and art. 19-4 RR. The implication is that the possibility and any defences against liability claims for cargo damage against such a performing party is governed by the law applicable to the claim (the lex causae).

This follows from the reference made in art. 1.7 RR to the "performing party", which term is defined in art. 1.6 RR. For the carrier see art. 1-6 (a) RR.

The same conclusion is reached albeit on different grounds by D.R. Thomas, 'An analysis of the liability regime of carriers and maritime performing parties', in: D.R. Thomas (ed.), A new Convention for the Carriage of Goods by Sea - The Rotterdam Rules, Lawtext, 2009, p. 57. See also: T. Fujita, 'The Comprehensive Coverage of the New Convention: Performing Parties and the Multimodal implications', 44 Texas International Law Journal, 2009, p. 349 ff., who concludes on p. 370 that it is ambiguous under art. 1.6 RR, whether the definition of performing party includes an employee of a carrier. See also the Report from the $19^{\text {th }}$ Session, A/CN.9/621, p. $28 \mathrm{ff}$., $\S 128 \mathrm{ff}$. See art. 4.1 (c) RR and art. 19-3 RR.

Compare the rule under art. 19.4 and art. 4 (b) and (c) RR with the rules on liability of the carrier under art. 17 and 18 RR, respectively the maritime performing party under art. 19.1 and $19.3 \mathrm{RR}$. See also the discussion in the Report of the $12^{\text {th }}$ Session of the Working Group, A/CN.9/544, and the $19^{\text {th }}$ Session of same, A/CN.9/621, p. $28 \mathrm{ff}$., § $127 \mathrm{ff}$. For an overview of the debate in CMI's International Sub-Committee about this issue, see: M. Sturley, 'The treatment of Performing Parties', CMI Yearbook, 2003, p. 232 ff. See also: A/CN.9/WG.III/WP.21, at p. 14, § 19.

The cargo- and carriage-related obligations listed in art. 1-6 RR are repeated in art. 13.1 RR with one addition, i.e. 'the carrier shall ... properly and carefully ... keep ... the goods." Despite the omission in art. 1.6 RR there can be no doubt that that the notion of the (maritime) performing party also extends to a party e.g. a warehouse or a terminal operator 
as a maritime performing party, an independent contractor must (undertake to) perform any of the carrier's obligations directly related to (what can be summarized as) the cargo-handling or carriage under the contract of carriage. ${ }^{95}$ This implies that under the facts of a given case sub-carriers ${ }^{96}$ and tug boats ${ }^{97}$ (carriage), stevedores and lightering operators (loading, handling, unloading), warehouse keepers and terminal operators (receive, care, keep, delivery), as well as independent lashing and stowage companies (handling, stowage, care) may qualify as maritime performing parties under the Rotterdam Rules. ${ }^{98}$

However the criterion seems to exclude independent contractors who merely assist ${ }^{99}$ in the performance of carriage or cargo-related obligations by others ${ }^{100}$, without performing any of these carrier's obligations themselves. ${ }^{101}$ Similarly it excludes independent contractors (who undertake to) perform other obligations of the carrier under the contract of carriage ${ }^{102}$, such as his duty to exercise due diligence $^{103}$ to make and keep the ship seaworthy ${ }^{104}$, to properly crew ${ }^{105}$, equip ${ }^{106}$ and supply ${ }^{107}$ the ship or his duty to prepare and issue transport documents/records ${ }^{108}$, as these obligations are only indirectly related to cargo-handling or carriage.

Not entirely clear is the position in relation to independent contractors such as a ship repair yard or a container supplier or repairer who perform the carrier's duty to exercise due diligence to make and keep the cargo holds in which the goods are to be carried and any containers supplied by the carrier in or upon which the goods are carried, fit and safe for their reception, carriage and preservation. ${ }^{109}$ Arguably, these 'cargo-worthiness' obligations of the carrier are so closely connected to the care for the goods that they should fall within the definition of art. 1.6 RR.

who stores and keeps (or undertakes to keep) the goods for the carrier in the performance of contract of carriage. See also:

See art. 1.6 and art. 13.1 RR. See also: F. Berlingieri, 'The Rotterdam Rules: The 'The Maritime Plus' Approach to Uniformity', EJCCL, 2009-2 P. 49 ff., p. 54-55, who based on the Report of the Working Group on the work of its Ninth Session, document $A / C N .9 / 510$, p. 32 ff., § 96-104 points out that: "The list of obligations has been adopted in order to restrict persons, called performing parties, to persons that perform a physical activity directly related to the carriage of goods, thereby excluding both activities only indirectly related to the carriage, such as repairs of the goods or of their packing and non-physical activities, such as documentary services."

D.R. Thomas, op. cit., 2009, p. 57 gives the following examples: intra-port transporters, feeder carriers, lightering and barge operators and sea carriers to whom the carriage has been sub-contracted.

Assuming that the tug is actually towing the ship and is not merely assisting/accompanying a ship sailing and navigating by its own force.

See: A/CN.9/WG.III/WP.21, p. 12 ff.; A/CN.9/WG.III/WP.21/ Add.1, p. 13, § 22.

E.g. a port pilot advising the master how to navigate the ship or harbour tugs assisting in the mooring of the vessel. I.e. by the carrier or a maritime performing party.

Support for this conclusion can be found in the Travaux Préparatoires, see: A/CN.9/WG.III/WP.21, at p. 13, § 17 where the example is given of a security company that guards a container yard.

Cf. Berlingieri, op. cit., EJCCL, 2009-2, p. 54-55. See also: A/CN.9/WG.III/WP.21/Add.1, p. 13, § 22.

See art. 14 (a) and (b) RR.

E.g. a ship repair yard.

E.g. a crewing agency.

E.g. a ship chandler.

E.g. a bunker supplier.

E.g. a ship's agent. See art. 35 and 36 RR. Cf. Berlingieri, op. cit., EJCCL, 2009-2, p. 55.

See art. 14 (c) RR. 
- "to the extent that such person acts, either directly or indirectly, at the carrier's request or under the carrier's supervision or control": Finally, in order to qualify as a maritime performing party, the person in question must be retained directly or indirectly by the carrier and not by any of the parties interested in the cargo. ${ }^{110}$ The Rotterdam Rules expressly permit parties to the contract of carriage to agree that the loading, handling, stowing or unloading of the goods is to be performed by the parties interested in the cargo. ${ }^{111}$ Of course also the cargo interests may decide to delegate the performance of these duties to an independent contractor, but that party is by definition not a (maritime) performing party under art. $1.7 \mathrm{j}^{\circ}$ art. $1.6 \mathrm{RR}$.

39. In order to distinguish the maritime performing party concept from inland carriers ${ }^{112}$, art. 1.7 RR provides that a performing party is to be considered a maritime performing party if and to the extent that it performs any of the carrier's obligations during the period from arrival of the goods at the port of loading of the ship to the moment of their departure from the port of discharge of a ship. ${ }^{113}$ In other words, his involvement with the performance of the contract of carriage must have taken place during the maritime stage of the transport as opposed to any inland stages of the contracted carriage.

40. As a measure to protect independent contractors active in non-Contracting States from incurring liability as a maritime performing party, the Rotterdam Rules require a sufficient connection between the activities of the maritime performing party and the territory of a Contracting State. The relevant art. 19.1 (a) $R^{114}$ is cited here first for easy reference:

Article 19. Liability of maritime performing parties

1. A maritime performing party is subject to the obligations and liabilities imposed on the carrier under this Convention and is entitled to the carrier's defences and limits of liability as provided for in this Convention if:

(a) The maritime performing party received the goods for carriage in a Contracting State, or delivered them in a Contracting State, or performed its activities with respect to the goods in a port in a Contracting State; (...)

See also art. 1.6 (b) RR, which expressly mentions the shipper, the documentary shipper, the controlling party and the consignee.

See art. 12.2 RR, which provides also that reference to this agreement (usually a variation on the FIO-clause (Free In and Out of the ship)) must be made in the contract particulars (see art. 36 RR).

As follows from the last sentence of art. 1.7 RR, inland carriers may only be considered "maritime performing parties" if their services are provided exclusively within the port area. Van der Ziel gives the following examples: "a fork lift truck operator shifting a container within a terminal, a road haulage carrier transferring a transshipment container from one terminal to another in the same port or a rail operator shunting railcars with goods within the port area in order to compose a full train." See: G.J. Van der Ziel, 'Multimodal aspects of the Rotterdam Rules', CMI Yearbook 2009, p. 309. See art. 1.7 RR.

See about art. 19.1 (a) RR also the contribution of P. Mankowski, 'The Rotterdam Rules, Scope of application and freedom of contract' in this issue of EJCCL, 2010-1, § II-6. 
41. Art. 19.1 (a) RR limits the scope of application of the maritime performing party concept to situations where the maritime performing party (alternatively): (i) receives for carriage or (ii) delivers the goods or (iii) performs his activities with regard to the goods in a port in a Contracting State. Thus an independent contractor whose services as a sub-carrier or in relation to the handling of the cargo are limited exclusively to the territory of non-contracting states need not adapt his liability insurance cover to the possibility of a direct action against him as a maritime performing party.

42. The scope rule for maritime performing parties in art. 19.1 (a) RR differs in several ways from the general scope rule for contracts of carriage in art. 5.1 RR. First, art. 19.1 (a) RR has a connecting factor unknown to art. 5 RR, i.e. the place of performance of the cargo-related activities by the maritime performing party. This factor was obviously necessary in relation to those maritime performing parties who are not sub-carriers and therefore do not receive or deliver the goods, but who nevertheless engage in activities in relation to the cargo. Second, whereas all three connecting factors in the scope rule in art. 19.1 RR can only apply to the maritime stage of the transport ${ }^{115}$, two of the connecting factors in the scope rule of art. 5 RR may also refer to non-maritime - inland - places of receipt or delivery in contracting states.

43. Third and foremost, the connecting factors in the scope rule of art. 19.1 (a) RR focus on the place where the maritime performing party received or delivered the goods for carriage, instead of the place of receipt or delivery by the carrier under art. 5 RR. ${ }^{116}$ Furthermore, whereas art. 5 RR focuses on the contractually agreed ${ }^{117}$ places of receipt and delivery by the carrier, it seems that art. 19.1 (a) RR refers to the actual ${ }^{118}$ places of receipt and delivery by the maritime performing party. Of course in a given case these places may very well overlap. ${ }^{119}$ However in This follows from the material restriction of the maritime performing party concept in art. 1.7 RR to the maritime stage of the transport only. See above $§ 4.3 .3$, No. 39. P.M.

116 Compare art. 5.1 (a) and (c) RR.

117 This follows from the words "if, according to the contract of carriage, any of the following places is located in a Contracting State ...(a) the place of receipt; ... (c) the place of delivery; ...", in art. 5 RR. See also: Mankowski, op. cit., EJCCL, 2010, $\S$ II.1.

This is suggested at least by the absence of a reference to the contract of carriage in art. 19.1 RR and by the rather factual wording used in art. 19.1 (a) RR: "if: the maritime performing party received the goods for carriage in a Contracting State, or delivered them in a Contracting State," which is markedly different from the more abstract wording used in art. 5 RR.

119 l.e. if the place of receipt or the place of delivery under the contract of carriage is also the place where the maritime performing party receives or delivers the goods as an agent/independent contractor for the carrier. Also where the port of loading or the port of discharge under the contract of carriage coincides with the place of receipt or delivery of the goods by the maritime performing party. See art. 5 and art. 19.1 (a) RR.
} 
other cases ${ }^{120}$, this divergence between these two scope rules has the significant and clearly intended result that although the contract of carriage as a whole is governed by the Rotterdam Rules, the liability and right to invoke carrier's defences and limitations of liability ${ }^{121}$ of an independent contractor who would otherwise qualify as a maritime performing party, are not governed by these rules ${ }^{122}$, but by the applicable national law.

\subsection{DIRECT ACTION AGAINST THE MARITIME PERFORMING PARTY}

\subsubsection{Direct action}

44. The fourth topic for which a uniform rule has developed is the possibility of pursuing a direct action against the person who actually performs the (stage of the) carriage during which the damage occurred, the actual carrier. Again the basic idea originates from air law ${ }^{123}$ and has spread from there to several other transport law conventions. ${ }^{124}$ As was discussed already above, the Rotterdam Rules have transformed and extended the concept of the "actual carrier" into that of the "maritime performing party", which not only includes (any) sub-carriers who (undertake to) perform (part of) the carriage, but also any independent contractors who (undertake to) perform any of the cargo-related obligations of the carrier under the contract of carriage during the maritime stage of the transport. ${ }^{125}$

45. Practically speaking, a direct action against the maritime performing party would solve most of the abovementioned ${ }^{126}$ problems in the recovery of cargo damage claims because it provides the cargo interests with one or more additional debtors, who usually will have easily traceable assets ${ }^{127}$ on which if necessary the claim for compensation of cargo damage may be enforced. Last but not least, the direct action against a maritime performing party may offer the cargo claimant up to four (!) additional grounds of jurisdiction under art. $68 \mathrm{RR}^{128}$ as well as an alternative to a possibly binding choice of court agree-

E.g. where the maritime performing party as sub-carrier performs only a part of the sea leg. See also: Mankowski, op cit., EJCCL, 2010, § II.6.

The scope rule in art. 19-1 RR determines not only whether a direct action against a maritime performing party exists, but is also a condition precedent to the right of that same party under art. 4-1 RR to invoke the defences and limitations of liability of the carrier under the Rotterdam Rules. The rationale for this connection between the direct action and the protection of the mandatory liability regime seems to be that maritime performing parties should take the bitter with the sweet. See: Sturley, CMI Yearbook, 2003, p. 235.

Cf. Mankowski, op. cit., EJCCL, 2010, § II.6.

See art. II and V Guadalajara Convention.

See art. 10-2 Hamburg Rules, art. 4-2 CMNI, art. 39 ff. MC, art. 19 RR.

See above $\S 4.3 .3$, No. $36 \mathrm{ff}$.

See above in $\S 3.1$, Nos. 6 and 7.

E.g. a ship or the business premises from which the stevedores or a terminal operator works.

The jurisdictional grounds in art. $68 \mathrm{RR}$ mirror those in art. $66 \mathrm{RR}$, but might differ in a given case because the grounds in art. 66 RR refers to the courts of (i) the carrier's domicile, (ii)-(iii) the contractually agreed places of receipt and delivery, (iv) the initial port of loading of the ship and ( $v$ ) the ultimate port of discharge from a ship under the contract of carriage as a whole. Art. 68 RR by contrast applies to the courts of (i) the maritime performing party's domicile, (ii)-(iii) the actual ports of receipt and delivery by the maritime performing party or (iv) the port where the maritime performing party performed his activities with respect to the goods. See also: O. Cachard, 'Jurisdictional Issues in the Rotterdam Rules: Balance of Interests or Legal Paternalism', EJCCL, 2010-1, § I.A.2, No. $14 \mathrm{ff}$. 
ment with the carrier under art. 67.2 RR. ${ }^{129}$ For all these reasons any remaining uncertainty about the identity of the carrier will be a less pressing concern for a cargo claimant.

\subsubsection{Period of Responsibility}

46. The third cumulative requirement ${ }^{130}$ for the direct action against the maritime performing party, is that the damage event must have occurred during the period of responsibility ${ }^{131}$ of the maritime performing party under art. 19.1 (b) RR. As far as relevant here, this provision reads follows:

Article 19. Liability of maritime performing parties

1. A maritime performing party is subject to the obligations and liabilities imposed on the carrier under this Convention and is entitled to the carrier's defences and limits of liability as provided for in this Convention if:

(a) ...; and

(b) The occurrence that caused the loss, damage or delay took place:

(i) during the period between the arrival of the goods at the port of loading of the ship and their departure from the port of discharge from the ship;

(ii) while the maritime performing party had custody of the goods; or

(iii) at any other time to the extent that it was participating in the performance of any of the activities contemplated by the contract of carriage.

47. Art. 19.1 (b) RR offers the claimant the choice between three alternative definitions of the period of responsibility of the maritime performing party. Alternative (i) which focuses on the maritime stage of the transport ${ }^{132}$ is suitable to be used in relation to sub-carriers. Alternative (ii) focuses on the taking over and keeping of the goods and is aimed primarily at storage keepers ${ }^{133}$ although it may equally apply to sub-carriers. ${ }^{134}$ Finally alternative (iii) is directed at maritime performing parties who assist in the performance of cargo-related obligations under the contract of carriage without carrying or taking custody of the goods. ${ }^{135}$

See more extensively, Cachard, op. cit., EJCCL, 2010-1.

The other requirements are the definitions in art. 1.6 and $1.7 \mathrm{RR}$, see above $\S 4.3 .3$, Nos. $36 \mathrm{ff}$. and the formal scope rule in art. 19.1 (a) RR, see above $\S 4.3 .3$, Nos. $40 \mathrm{ff}$.

M. Tsimplis in: Y. Baatz, C. Debattista a.o., The Rotterdam Rules: A Practical Annotation, Informa, London, 2009, p. 64, No. 19-02 overlooks art. 19.1 (b) RR when he states that there is nothing on the period of responsibility of the maritime performing party within the Convention.

It is noteworthy that whereas art. 1.7 RR refers to the ports of loading and discharge of " $a$ ship", art. 19.1 (b) (i) RR uses the word "the ship". In view of the Travaux Préparatoires it is likely that this inconsistency does not indicate a significant shift in meaning, and is merely a clerical error. In the Report of the $19^{\text {th }}$ Session of the Working Group, 16-27 April 2007, A/CN.9/621, p. 32, § 141, 153 the revised wording of art. 19.1 still contained the words "a ship". Then in A/CN.9/WG.III/ WP.101, p. 19 this was changed in "the ship". Unfortunately the Report of $21^{\text {st }}$ Session of the Working Group, 16 June-11 July 2008 does not shed much light on this alteration, see: A/CN.9/645.

E.g. a warehouse, a terminal operator or a lightering company.

With regard to the maritime stage of the transport there is overlap with alternative (i). Alternative (ii) may however be relevant where the sub-carrier already took over the goods prior to their arrival at the port of loading or continued to hold them in his care even after their departure from the port of discharge. It follows that the period of responsibility of a maritime performing party may extend even to non-maritime stages of the transport provided that he has custody of the goods.

E.g. stevedores, lightering companies, lashing and stowage companies. If the above analysis in 


\subsubsection{Liability Regime}

48. If the three cumulative requirements ${ }^{136}$ for a direct action against the maritime performing party are met, then under art. 19.1 RR the maritime performing party is subject to the same liability regime as the carrier under the Rotterdam Rules. This implies that during his period of responsibility as defined under art. 19.1 (b) RR and in relation to the carriage or cargo-related obligations (undertaken to be) performed by him, the maritime performing party is subject to the same obligations and liabilities and entitled to the same defences and limits of liability as the carrier under the Convention.

49. However, it does not follow from this that the legal position of the maritime performing party is in all respects identical to that of the carrier. First, whereas the carrier is party to the contract of carriage with the shipper and the consignee, the maritime performing party has no contractual relation with the cargo claimant who may bring a direct action against him under art. 19.1 RR. Although the carrier's liability is contractual and the maritime performing party's liability statutory by nature, both liabilities are imposed by mandatory law. ${ }^{137}$ Second, the period of responsibility and the obligations performed by the maritime performing party will often differ significantly from those of the carrier. Only in case a carrier ${ }^{138}$ sub-contracts the performance of the entire contract of carriage to a single maritime performing party will this be different. Third, if the carrier assumes other obligations or accepts higher limits of liability under the contract of carriage than those imposed by the Rotterdam Rules, this does not bind the maritime performing party unless he expressly agrees to it. ${ }^{139}$

50. In line with the liability regime applicable to the carrier and the division of the burden of proof under the Rotterdam Rules, the cargo claimant must prove that the occurrence that caused the loss, damage or delay took place during the period of responsibility of the maritime performing party in order to make him prima facie liable. ${ }^{140}$ It is then up to the maritime performing party to relieve himself from this liability by proving that the cause of the loss, damage or delay is not attributable to his fault or to the acts or omissions of any person to whom he has entrusted the performance of any of the carrier's obligations under the contract of carriage. ${ }^{141}$ Alternatively, the maritime performing party may also relieve himself from the prima facie liability by proving that one or more of the exemption grounds of the carrier's caused or contributed to the loss, damage or delay. ${ }^{142}$

51. If the cause of the damage is unknown, the maritime performing party will remain liable to compensate the cargo damage. Should the maritime performing party however succeed in disproving his

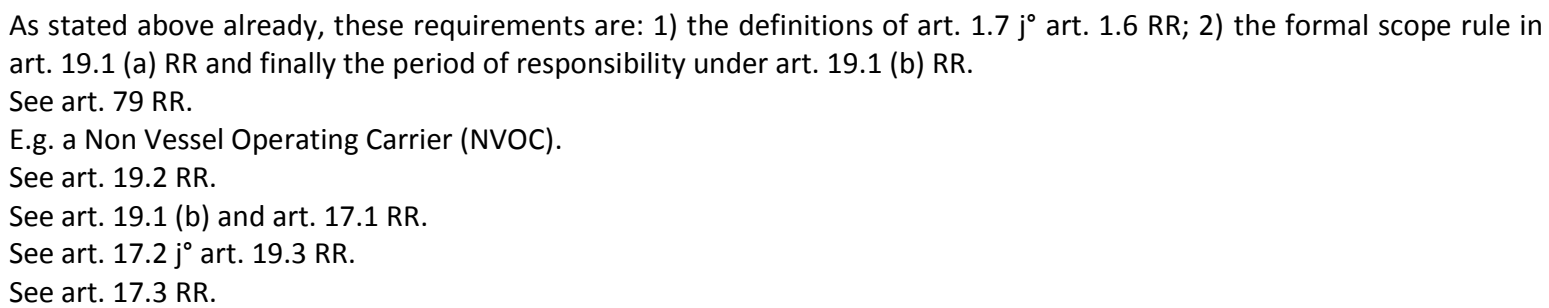


prima facie liability, then the burden of proof shifts to the cargo claimant again who may prove that the maritime performing party is liable for one or more of the causes listed in art. 17.4 and 17.5 RR. It should be noted here, that although the maritime performing party is liable for the breach of his obligations caused by the acts and omissions of any person - whether employee, agent or independent contractor to whom he has delegated performance of the carrier's obligations ${ }^{143}$, he is not responsible for the fault of the carrier, his agents and employees or any other maritime performing parties even if their fault causes or contributes to the cargo damage during his period of responsibility. ${ }^{144}$

52. An imaginary example may help to illustrate the point. During lightering operations a floating crane discharges containers from a container ship and loads them on to a barge. Because of an error made in the ballasting of the ship, the ship suddenly lists to starboard, causing the floating crane to turn over and several containers to fall overboard from the barge. The cargo claimant may easily establish a prima facie liability on the part of carrier $C$, as well as on the part of ship-owner $S$ (sub-carrier), floating crane operator L (lightering company) and barge-owner B as maritime performing parties, by proving that the occurrence which caused the cargo damage took place during their period of responsibility. $\mathrm{C}$ as carrier is obviously liable for the breach of its obligations caused by the acts and omissions of (employees of) $\mathrm{S}$ and of the master and crew of the ship ${ }^{145}$ and so is $\mathrm{S}$ as maritime performing party. ${ }^{146}$ In principle, $\mathrm{L}$ and $\mathrm{B}$ are not responsible for $\mathrm{S}$ or for the ballasting error made by the crew of the container ship, however if $L$ is unable to relieve itself from liability by proving that the cause of the accident is not attributable to its fault or its servants, then $L$ will remain liable.

\subsubsection{Burden of proof}

53. What may prove problematic in future maritime practice is that normally the burden of proof that the damage occurred during the period of responsibility of the carrier also entails that the cargo claimant must prove that the goods were (still) in undamaged condition at the time that this period began and were damaged at the time that it ended. In cases where the period of responsibility of the maritime performing party does not coincide with that of the contract of carriage as a whole, there may have been a preceding transport stage whether by land or by sea or a subsequent stage or both. In that case it is most unlikely that the condition of the goods would be inspected before the maritime stage started and once again when it ended. It is also clear that it would be highly unpractical, expensive and delaying to introduce such inspections at intermediary stages of the transport.

54. It follows therefore that it may impose an almost diabolical burden of proof on the cargo claimant if he has to prove the sound condition of the cargo at the time that the period of responsibility of the maritime performing party starts. On the other hand it is hard to deny a maritime performing party, who

See art. 19.3 RR.

See art. 19.1 (b) RR.

See art. 18 (a), (b) and (c) RR.

See art. 19.3 RR. 
may have only limited knowledge of the outward appearance of the (containerised) cargo during a relatively short period of time, the right to challenge the cargo claimant's allegation that the occurrence which caused the damage took place during his period of responsibility. Furthermore, the cargo claimant has an alternative, which is to direct his cargo claim against the carrier. It remains to be seen how the courts will deal with this problem once the Rotterdam Rules enter into force.

\subsubsection{Joint and several liability}

55. In the event that a maritime performing party is liable, the carrier will be liable as well, because any breach of his obligations caused by acts or omissions of the maritime performing party, his employees, agents and sub-contractors is attributable to the carrier. ${ }^{147}$ As is clarified in art. 20.1 RR such liability of the carrier and one or more maritime performing parties is joint and several. This implies that the cargo claimant has the right to pursue his cargo claim to the full amount (of the applicable liability limit) against each of joint debtors, but can recover his damage compensation only once. ${ }^{148}$

56. What it also implies is that there may be recourse claims between the carrier, the maritime performing parties and vice versa if the party who is forced to pay the cargo claimant is not the one who in the internal relationship between the co-debtors is the one who should ultimately bear this loss (to this degree). Often a clear risk allocation between the carrier and maritime performing party will follow from

their contract. ${ }^{149}$ If however several maritime performing parties are engaged at the same time ${ }^{150}$, then it is quite possible that there is no contractual link, not to mention a clear risk allocation agreed between these maritime performing parties and the carrier. In that case problems of jurisdiction and applicable law may easily arise. Unfortunately the Rotterdam Rules do not provide any uniform rules or guidance with regard to these recourse actions, as the matter is entirely left to national law.

\section{CONCLUSION}

57. Despite the above reservations, it is submitted that the concept of the maritime performing party in the Rotterdam constitutes a moderate step forward in the development of uniform transport law and that the drafters of the Rotterdam Rules have managed to arrive at a fairly balanced result in which maritime performing parties have been brought under the protection of the mandatory liability regime of the Rotterdam Rules at the price of being subject to a direct action in case the occurrence which caused the cargo damage took place during their watch.

See art. 18 RR and art. 17.2 and 17.4 RR.

See art. 20-2 RR which states that the aggregate liability of all liable person shall not exceed the overall limits under the Rotterdam Rules.

E.g. a charter-party, a contract of carriage, a storage or a stevedoring contract.

E.g. if there is a chain of sub-carriage contracts and several independent contractors performing bits and pieces of the main contract of carriage. 